\title{
Епидемиология на генетичните слухови увреди
}

\author{
Д. Попова \\ УМБАЛ „Царица Йоанна“ при МУ - София \\ Катедра по УНГ-болести
}

\begin{abstract}
Deafness is the most common sensory defect, affecting 1-1,5 per 1000 children. Heritable forms of hearing loss can be congenital or delayed onset; conductive, sensorineural, or mixed type; mild to profound in degree; progressive or nonprogressive; unilateral or bilateral and symmetrical or asymmetrical in severity and configuration.

The genetic syndromes that include hearing loss are commonly classified according to the other systems involved where as the nonsyndromic hearing disorders have been classified by their audiological characteristics, age of onset, presence or absence of progression, and mode of inheritance. Most authors attribute 75\% to $80 \%$ of genetic deafness to autosomal recessive genes and $18 \%$ to $20 \%$ to autosomal dominant genes, with the remainder classified as X-linked, or chromosomal, disorders.
\end{abstract}

\section{Въведение}

Честотата на хората от различни възрастови групи с намаление на слуха (< от $40 \mathrm{~dB}$ ) варира около 8,2 на 1000 според проучванията, извършени на територията на Европейския съюз. Неонаталните слухови скринингови програми позволяват установяването на намалението на слуха от раждането. Страните, въвели тези скринингови програми, съобщават за честота на слухови увреди около $1-1,5$ на 1000. С възрастта процентьт на хората с увреден слух се увеличава и стига до $30 \%$ във възрастовата група над 65 години.

Изучавайки етиологията на слуховите увреди, се установява, че една от основните причини за тежката слухова загуба (и/или практическата глухота) в неонаталния период и ранното детство е генетична. Генетичните фактори са причина и за късните слухови увреди.

Първите епидемиологични проучвания за наследствеността при слуховата загуба датират от 19. век и това ca Nance и Pandya; Bell и Fay, последвани от публикациите и откритията на Mendel. Приема се, че причините за слуховите увреди са генетични и фактори на околната среда.

\section{Факторите на околната среда}

В групата на факторите на околната среда влизат вирусни инфекции, ототоксични лекарства, травми и експозиция на шум и вибрации. Масовите имунизации, като превенция на редица вирусни заболявания, намаляват заболяемостта от менингити, която в миналото е представлявала една от основните причини за това заболяване. 
В групата на вирусните инфекции е задължително да се разгледа вродената цитомегаловирусна инфекция (CMV) като основен причинител на слухови увреди (1). Цитомегаловирусьт се предава от майката на плода по време на бременността. Едновременно със слуховия анализатор понякога се уврежда ЦНС, настьпват слепота, епилепсия и ментална ретардация. Слуховте увреди могат да са дефинитивни и прогресивни. Голяма част от цитомегаловирусните инфекции не се проявяват при раждането на детето, а само около $15 \%$ (2) са с проявена слухова увреда. Последната може да настъпи между 6-месечна и 5-годишна въ3раст, като степента на слуховата увреда варира в доста широки граници: от средна до пълна, от едностранна до двустранна. Цитомегаловирусната инфекция се доказва доста трудно и може да се мисли за нея при наличие на IgM в пъпната връв или крьвта на новороденото. Най-точното изследване е PCR (лабораторна реакция, установяваща наличието на ДНК на CMV), чрез която се установява наличието на вирусната инфекция.

\section{Генетичната слухова загуба}

Генетичната слухова загуба може да се разглежда като доминантна или рецесивна (2). Гените, определящи намалението на слуха, могат да са разположени върху автозомите (от 1 до 22) или върху X - хромозомата, те се намират в ядрото на клетката. В общ план рецесивните слухови увреди причиняват прелингвалната слухова загуба, докато доминантните форми са постлингвални и прогресивни, естествено с наличие на изключения. При родствена връзка между родителите в повечето случаи се приема, че причината за слуховите нарушения са генетични (автозомно-рецесивни), като при някои фамилии фенотипната проява може да варира между децата на семейството. Дори при семейства с доказана наследствена слухова загуба децата може да не проявят очаквания фенотип. Това се обеснява с непълна пенетрация, последната може да се прояви с напредване на възрастта. Някои форми на наследствена слухова загуба са свързани с мутации в митохондриалния геном (mtDNA) (3). Последните могат да бъдат хетероплазматични (т.е. намират се само в някои от копията на митохондриалния белтьк) и хомоплазматични (намират се във всички копия на митохондриалния белтьк). Различните мутации на mtDNA, независимо дали придобити или наследствени, са свързани със синдромални или несиндромални слухови увреди. Повечето са хетероплазматични и са свързани със системни невромускулни наруше- ния, което се обяснява и с ролята на митохондриите при синтеза на АТФ (осигуряващ енергията на клетката). Такива заболявания са: Kearns-Sayre синдром; MELAS; MERRF - всички с проява и на слухови нарушения. Първите несиндромални mtDNA са открити в арабско - израелски фамилии. При тези семейства нарушенията са хомоплазматични, те са $\mathrm{A} 1555 \mathrm{G}$ мутации и са на $12 \mathrm{~S}$ rRNA гена, с начало на фенотипна проява от детството. При други членове на тези фамилии със същите мутации фенотипната изява се отключва при прилагането на аминоглюкозоиди, и то още в началото на лечението (отключва се от ниски дози от аминоглюкозоида) (4). Наличието на mtDNA в кохлеата допринася за ранната проява на пресбиакузис, поради ранно настъпилите нарушения в оксидативните процеси. Дали фенотипните прояви са синдромални, несиндромални или възрастово обусловени слухови увреди, клиничната проява на mtDNA мутация е високо вариабилна и в някои случаи се влияе от факторите на обкрьжаващата среда или мутиралите митохондриални гени.

С развитието на молекулярната биология са открити голям набор от гени, определящи процесите на слуховото възприятие и анализ на звуковите дразнители както при нормално чуващите индивиди, така и на слухово увредените. Открити са около 200 гени, чиито мутации са свързани със слухова загуба и при генетичните тестове се поставя точна диагноза на унаследените форми на слухови увреди.

Мутацията на конексина е основната причина за автозомно-рецесивните несиндромални форми на глухота. Гените на глухотата имат уникални характеристики, които я разграничават от другите форми на конексин асоциирани болести, това са и около 70-80\% от причините за прелингвалните форми на глухотата. GJB2 мутациите са основните причини за тежките форми на слухова загуба. При пациенти, при които не е открит GJB2 (за автозомно рецесивна несиндромална слухова загуба), може да се изследва мутация на OTOF ген, която е свързана и със слухова невропатия (5).

Съществуват различни типове мутации, повечето от които са мутации на протеина, докато при други една аминокиселина е заменена от друга. При тези форми на генетични промени се наблюдава повишена продукция на веществото, но без да се изпълнява необходимата функция. С развитието на молекулярната биология се разбират повече от детайлите в биологията на слуха и глухотата чрез идентификацията на повече от 40 гена, свьрзани с несиндромалните форми на глухотата. При бозайниците вьтрешното ухо и по-точно ципестият лабиринт е изграден от мембранозни структури, които 
е необходимо да осигуряват електроцелуларния метаболизъм, необходим за съществуването на нормалната функция на външните и вътрешните слухови клетки на Кортиевия орган. Базолатералната повърхност на слуховите клетки е заобиколена от перилимфа с йонен състав, аналогичен на екстрацелуларни течности. Стереоцилията на слуховата клетка е потопена в ендолимфата (в нея навлизат $\mathrm{K}+$ и се изнасят на $\mathrm{Na}+$ ) и се осигурява концентрация, аналогична на интрацелуларните течности. Слуховото дразнене предизвиква комплексни процеси в слуховите клетки с начални механични промени. Тези процеси започват от стереоцилията на върха на клетката, която се накланя и води до проникване на К + ендолимфатични йони. К+ йони са изхвърлени от базолатералната страна на клетката в интерстициалното пространство на Nuel. След това преминават в клетките на Deiter през специфични канали, свързани в цепковидна контактна мрежа. Тя е свързана с транспорта на инозитол трифосфат. Преминаването на тези молекули през цепковидните контакти води до освобождаване на АТФ в ендолимфата и активацията на специфичните рецептори в ендолимфатичната страна на подпорните епителни клетки. Този процес е последван от разпространяване на интрацелуларни $\mathrm{Ca} 2+$ вълни и осикулации, които са в основата на нормалната фукция на вътрешното ухо.

Основните структури, участващи в цепковидните контакти на вътрешното ухо, са белтьците на конексина (CX26 и CX30) и двата белтъка са в основата на нормалната функция на вътрешното ухо и слуховите клетки в невросензорния епител. CX30 участва и в генерирането на ендокохлеарния потенциал.

Пет са основните форми на конексина (CX26; СХ30; СХ31; СХ32; СХ43) и са свързани със слуховата загуба, включваща синдромални и несиндромални форми на глухотата (6).

\section{Клинична диагноза}

В клиничната практика и в литературата преди 1998 година слуховите загуби са се категоризирали като звукопроводна или звукоприемна загуба на слуха. Степента на слуховата загуба се изчислява чрез честотния диапазон на звукопроводната част на тоналната прагова аудиометрия, изразена чрез чисти тонове. Тези данни са най-общи и могат да се използват като предварителна оценка на клиничното състояние на пациента. Необходимо е тоналната прагова аудиометрия да бъде последвана от допълнителни изследвания на слуховата функция. Това се налага поради големия процент на слухова невропатия (или диссинхрония) между 10 и $40 \%$ при новооткритите форми на слухови увреди при децата от рисковите форми.

Препоръчителният набор от аудиометрични изследвания е:

- Тимпанометрия и рефлексометрия;

- Отоакустични емисии;

- Слухови стволови евокирани потенциали (ССЕП);

- Електрокохлеография или ASSR.

C тези изследвания се постига по-точно и ясно определение на състоянието на слуха, както и очакваните резултати от последващото лечение.

При пациенти със звукопроводно намаление на слуха очакваните резултати са:

- Нормална или променена тимпанограма;

- Липсващ или абнормален рефлекс на стапедиалния мускул;

- Липсващи OAE;

- ССЕП изоставянето в латентните времена и пикове отговаря на звукопроводното намаление на слуха от тоналната прагова аудиометрия.

Това са пациенти, в повечето случаи подходящи за оперативни интервенции и консервативно лечение.

Пациенти със звукоприемно намаление на слуха от ТПА:

1. Пациенти с променени или липсващи външни слухови клетки, с нормални вътрешни слухови клетки и нормални нервни окончания;

- Звукоприемно намаление на слуха е от порядъка на 65 d/B;

- Нормална тимпанограма;

- Положителен рефлекс на стапедиалния мускул;

- Липсващи OAE;

- ССЕП - латентните времена и пикове са около на прага на слуха на ТПА

Това са пациенти, подходящи за слухопротезиране със слухови апарати с широк динамичен диапазон.

2. Пациенти с промяна във вътрешните слухови клетки или променени нервни окончания - това са различни форми на слухова форма на невропатия или дисхрония.

- Нормална тимпанограма;

- Липсващ или абнормален рефлекс на стапедиалния мускул;

- Наличие на ОАЕ;

- ССЕП с изразен микрофонен потенциал изоставянето в латентните времена и пикове. 
С тези изследвания се откриват:

- функционални или неорганични слухови загуби;

- централни слухови загуби;

- а-лезии с ареи на дисфункция в резултат на липсващо развитие и растеж.

\section{Заключение}

Прогресът в установяването на генетичните форми на слуховата загуба чрез идентификация и характеристика на синдромалните и несиндромалните форми на глухота. Откриват се гените, причинили тези форми на слухови увреди с фенотипните и генотипните промени. Установявайки молекулярната диагноза на глухотата, се изяснява клиничната картина и степен на глухотата, очакваните резултати след евентуална кохлеарна имплантация. Генетичната диагностика на глухотата ще подобри лечението и прогнозата на състоянието на слуха стабилно или прогресивно. Родителите имат информация за наличие на фамилна глухота и степента на риска при следваща бременност. По този начин може да се дискутира реалната наследственост, степента на риска, при точно определяне на причината се дискутира и последващите възможности за лечение и прогноза на състоянието на детето.

\section{Литература:}

1. Barbi M, Binda S, Caroppo S, Amprossetti U, Corbetta C, Sergi P. A white role for congenital cytomegalovirus infection in sensorineural hearing loss. Pediatric infection dis J, 2003; 39-42.

2. Nance W, Pandya A. Genetic epidemiology of a deaf variety of the human race, Washington,DC:National Academy of Sciences; 1884.

3. Smith R, Bale J,White K.Sensoneural hearing loss in children. Lancet $200 ; 365 ; 879-890$.

4. Jaber L. Shohat M, Bu X, et al. Sensoneural deafness inherid as a tissue specific mitochondrial disorder. J Med Genet 1992; 29; 86-90.

5. Varga R, Avenarius M, Keley P, et al. OTOF mutations revealed by genetic analysis of hearing loss families including a potential temperature - sensitive auditory neuropathy allele. J med Genet 2006; $43 ; 576-581$

6. Cheng X, Li L, Brashears S; et al. Conexin 26 variants and auditory neuropathy/dys-synchrony among children in school for the deaf. Am J Med Genet 2005; 139A; 13-18

7. Grundfast KM. Atwood JL. Chuong D.: Genetics and molecular biology of deafness. Otolaryngology Clinics of North America. 32(6): 1067-88, 1999 Dec

8. Konigsmark BW. Gorlin RJ. Editors: Genetic and metabolic deafness, Philadelphia, 1976, WB Saunders.

9. Steel KP.: A new era in the genetics of deafness. New England Journal of Medicine. 339(21): 1545-47, 1998 Nov.

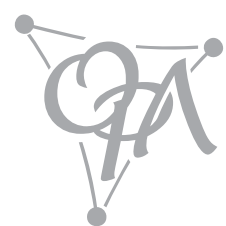

